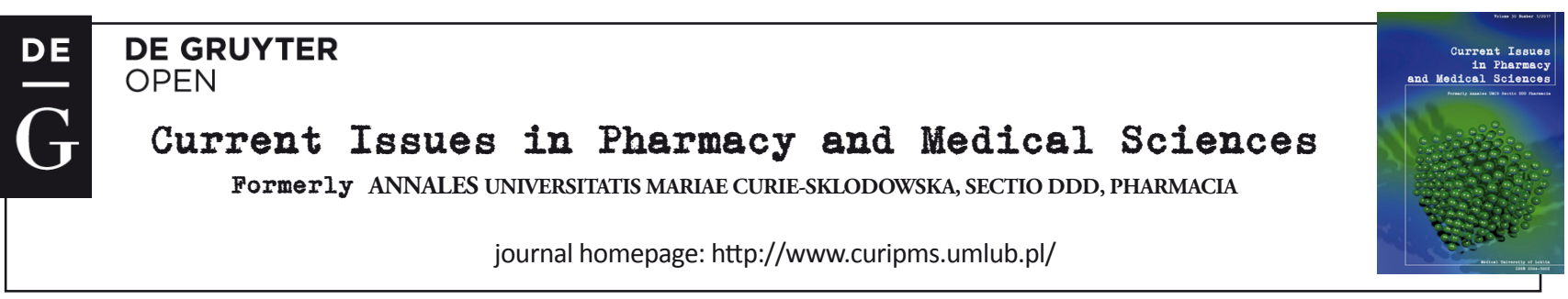

\title{
The blue pill (sildenafil) and its descendants: an overview
}

\author{
Tomasz Krzanowski ${ }^{1}$, Lila Dabkowska ${ }^{2}$, Monika Wujec ${ }^{1}$, Ewa Kedzierska ${ }^{2 *}$ \\ ${ }^{1}$ Chair and Department of Organic Chemistry, Medical University of Lublin, Chodzki 4A, 20-093 Lublin, Poland \\ ${ }^{2}$ Chair and Department of Pharmacology and Pharmacodynamics, Medical University of Lublin, Chodzki 4A, 20-093 Lublin, Poland
}

\section{ARTICLE INFO \\ Received 09 September 2017 Accepted 25 September 2017}

\section{Keywords:}

erectile dysfunction,

phosphodiesterase type 5

inhibitor,

PDE-5-inhibitor.

\begin{abstract}
An increasing number of men around the world suffer from erectile dysfunction (ED). Indeed, according to the sexuality study conducted by Professor Izdebski, 1 out of 10 men in Poland suffers from ED. The problem is found among men of any age, however, $60 \%$ of all patients are between 40 and 60 years old, thus in their prime, and who still want to fully enjoy life. Not only do the effects of ED affect a man, but they have influence on his relationship and partner as well. In spite of a growing awareness within society, the problem remains perceived as embarrassing, which leads patients to treat themselves on their own, delaying a visit to their doctors. Meanwhile, in many cases, ED may be the first symptom of more serious diseases, such as diabetes, or result from the sideeffects of applied drugs. A breakthrough in the oral medication treatment of ED was observed when a new phosphodiesterase type 5 inhibitor (PDE-5-inhibitor) - sildenafil citrate $\left(\right.$ Viagra $\left.^{\circ}\right)$ - was introduced. Nowadays, 5 active substances from this group are being applied. The current medical guidelines recommend PDE- 5 inhibitors as the firstline therapy for most men with $\mathrm{ED}$, irrespective of the cause and severity of the disease. Recently, sildenafil at the dose of $25 \mathrm{mg}$ came into the market without prescription. This paper presents an overview and update of the PDE-5 inhibitors.
\end{abstract}

\section{ERECTILE DYSFUNCTION - DEFINITION AND EPIDEMIOLOGICAL DATA}

Erectile dysfunction (ED) is the inability to develop and/ or maintain an erection necessary to have a successful sexual performance [1]. It has been diagnosed in an increasing number of men around the world [2]. According to the sexuality study conducted by Professor Izdebski, 1 out of 10 men in Poland suffers from ED. The problem is found among men of any age, however, $60 \%$ of all patients are between 40 and 60 years old, thus in their prime, and, hence, still have the desire to fully enjoy life. Moreover, among men older than 60 , ED occurs in more than $50 \%$ of the population [3]. Unfortunately, out of 1.5 million men suffering from ED, only $15 \%$ seek medical help. Not only are the effects of ED detrimental to a man's self-esteem, but they also have a negative influence on his partner and his sexual relationships. Still, in spite of a growing awareness within society, the problem remains perceived as embarrassing, which leads patients to treat themselves on their own, delaying a visit to their doctors even up to several years. Indeed, $16 \%$ of all patients only decide to seek professional help more than 4 years after the first symptoms are observed [4].

\footnotetext{
* Corresponding author

e-mail: ewa.kedzierska@umlub.pl
}

\section{THE MECHANISM OF ERECTION}

While flaccid, a penis is controlled by the sympathetic nervous system responsible for involuntarily reactions. Through the effect of adrenaline, vascular smooth muscles and the trabeculae of the corpus cavernosum are shrunk, and the flow of blood is low. As a result of sexual arousal (mechanical or psychogenic), the activity of the sympathetic nervous system decreases, while sympathetic neurons from the NANC group (nonadrenergic, noncholinergic) prevail and release nitric oxide - NO, which stimulates relaxation of the corpus cavernosum smooth muscle and produces erection. The compounds which are additionally released by these neurons, for instance, adenosine or vasoactive intestinal peptide (VIP), also result in an increased production of NO in the endothelium cells. NO connects with "guanylyl cyclase receptors", which conditions the production of highly energetic cyclic guanosine monophosphate (cGMP), which lowers the calcium ion concentration $\left(\mathrm{Ca}^{2+}\right)$ in muscle cells. As a consequence, vascular smooth muscles relax and the flow of blood is increased, which results in the stiffening of a penis and erection. After ejaculation, a penis returns to its flaccid state. The erection recedes due to the effect of phosphodiesterase type 5 enzyme (phosphodiesterase type 5 , PDE-5), which causes the decomposition of cGMP $[5,6]$. 


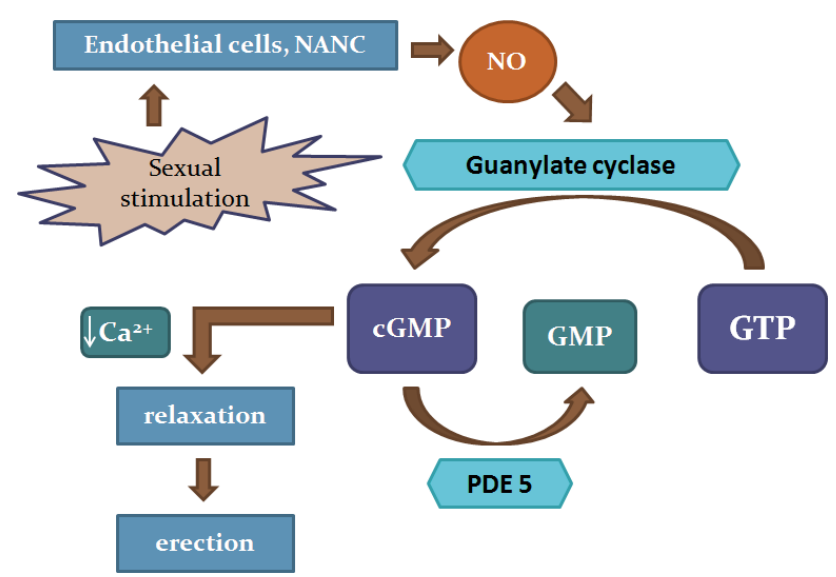

Figure 1. Physiological mechanism of penile erection

\section{Causes of ED}

There are a variety of ED causes. Generally, they can be divided into either physical and psychological, however, currently they are considered to involve factors from both groups [7]. The dysfunction may result from abnormalities in a penis structure or damage, yet this constitutes only a minority of patients. Much more frequently, ED are one of the symptoms accompanying more serious diseases [8]. They are found, for example, in $69,52 \%$ of all patients suffering from diabetes. Frequently, ED is also observed in the cases of cardiovascular and hormonal dysfunctions, kidney and spinal damage, obesity (men who exercise regularly have a lower risk of ED, although it may occurs among cyclists and jockeys). It is worth remembering that temporary ED might accompany any illness, even common cold, as the male system is weakened in such cases [9]. Nevertheless, the link between chronic disease and ED is most striking for diabetes (men suffering from it are 2-3 times more likely to have ED and may experience the problem as much as 10-15 years earlier), treated heart disease and hypertension [10]. Unfortunately, erectile dysfunctions may also constitute undesired side-effects of many types of medicine, especially antidepressants, antihistamines, antihypertensives or sedatives [11]. Furthermore, the problem often occurs or may be aggravated due to alcohol, cigarette or drug abuse, which are factors that may damage the blood vessels and reduce blood flow to the penis.

The psychological causes involve central blocking of erection mechanism, and are often linked to low self-esteem, relationship issues, too high expectations, stress, insecurity concerning sexual orientation or fear of a partner's eventual pregnancy. Thus, a number of issues can interfere with sexual feelings and cause or worsen ED [7,9,12].

\section{The diagnosis of ED}

Clinically, the diagnosis is based on anamnesis and physical examination, and may be supported by laboratory tests, e.g. measure of serum testosterone level [10].

\section{Treatment possibilities}

Presently, effective treatment of most ED cases is possible. Before a patient decides to undergo a pharmacological treatment, however, it is worth considering psychotherapy. Its aim is to make both partners aware of the fact that ED may result from getting older, is a natural phenomenon and is treatable. In addition, those patients who suffer from chronic diseases need to understand that an appropriate treatment may alleviate the dysfunction or even cure it completely [13]. An alternative for medications are vacuum devices (also called pumps) for ED: the penis is put inside a cylinder, and a pump draws air out of it, creating a partial vacuum around the penis. This causes it to fill with blood, hence provoking an erection. Nevertheless, the dominant element of the therapy is a pharmacological treatment. Sporadically, patients may also decide to undergo a surgical treatment. Herein, a penile prosthesis and sound wave stimulation (RENOVA method) are applied [14].

\section{PHARMACOLOGICAL TREATMENT}

\section{Testosterone preparations}

Balancing testosterone levels, especially among older men, contributes to the improvement of erection, as well as their libido [15]. Unfortunately, it is not enough to completely eliminate the symptoms. Among men with an appropriate testosterone level, the administration of the hormone does not produce desired effects [6].

\section{Alprostadil}

Synthetic prostaglandin (PGE1) administered in injections directly into the cavernous bodies of the penis (or inserted down the opening into the urethra) increases their blood supply, and after approximately 7 minutes to 2 hours, causes erection. Currently, it is seldom used owing to numerous undesired side-effects (erythema, perineum pain, fibrosis of cavernous bodies, penile deformation, blood pressure increase, dizziness and priapism) [16].

\section{Apomorphine}

Apomorphine is an agonist of dopaminergic (mostly D2) receptors in the brain. It induces selective activation in the nucleus paraventricularis, leading to erectogenic signals. The drug is administered sublingually, then dissolves rapidly and results in an erection in responders in approximately 20 min. By avoiding first pass metabolism through this route of administration, apomorphine avoids any significant interaction with food or other drugs. Unfortunately, it shows only $15 \%$ of effectiveness among patients with minor dysfunctions and may cause nausea and vomiting [17].

\section{Plant preparations}

Most of these are supplements. The few recognized drugs include extracts from Schisandra chinensis, sabal minor and guarana. Taken regularly, they may constitute an addition to a primary treatment. A single dose does not affect the dysfunction [18].

\section{Phosphodiesterase type 5 inhibitors (PDE-5-inhibitors)}

A breakthrough in the oral medication treatment was observed when a new PDE-5 inhibitor, sildenafil citrate (Viagra ${ }^{\circledR}$ ), was introduced by Pfizer in 1998 [19], and reached USA Food and Drug Administration (FDA) approval as the first oral medication to treat ED. The popular 'blue pill' brought about a real revolution, as when it entered 
the world of pop culture, ED stopped being a taboo. The drug blocks the aforementioned enzyme. This results in the increase of cGMP, facilitating the development and maintaining of erection. The undisputed success of sildenafil has led to a search for more selective PDE-5 inhibitors; approval by the FDA brought to the market, vardenafil and tadalafil in 2003, and in 2012 - avanafil [20]. Currently, there are several preparations that contain 5 active substances from this group: sildenafil, vardenafil, tadalafil, avanafil (approved worldwide for the treatment of ED) and udenafil (approved in Korea and few other countries). The in place American, as well as European Association of Urology guidelines recommend PDE-5 inhibitors as the first-line therapy for most men with ED, irrespective of the cause and severity of the disease. The mode of action of all the drugs is identical. They are effective at least in $60 \%$ of all cases, but still ineffective at least in $30 \%$ of all patients [10,21]. They also differ in chemical structure and in pharmacokinetic properties (availability/metabolism), which leads to differences in time to onset (timing of the clinical response), maximum drug plasma concentration, half-life and duration of action, and safety profile. Therefore, they cannot be treated interchangeably [22] (Table 1). The drugs are bio-equivalent, yet they may differ in pharmacokinetic properties due to various degrees of micronization of ingredients or tabletting methods. After the Viagra ${ }^{\circledR}$ patent expired in Europe in 2013, a number of generic drugs containing sildenafil were introduced to the market [23]. Last year, in Poland, sildenafil citrate at dose $25 \mathrm{mg}$, came into the market without prescription under several trade names. It is the first such case in Europe and second in the world. The question is open whether this was the right decision.

\section{Undesirable effects}

Unfortunately, PDE-5 inhibitors only facilitate the development of erection, without curing its causes. Moreover, their use is linked to numerous undesirable side-effects. The most common are dyspeptic disorders, nasal congestion, headaches and sudden reddening of face skin (flushing) connected with a sensation of heat, which occur due to PDE-5 inhibition. Owing to the fact that the inhibitors also block a retinal enzyme rhodopsin (phosphodiesterase type 6), their use (especially sildenafil and vardenafil; tadalafil and the others to a lesser degree) may result in a change of colour perception (seeing blue), and even loss of vision. What is more, because of the fact that phosphodiesterase enzyme is present in all muscles, including the ones found in heart, a serious complications might occur, including a myocardial infarction and death. Moreover, a long-lasting painful erection (priapism), especially resulting from inappropriate dosing, is a very frequent undesirable side-effect. Rare but very dangerous hypersensitivity reactions, such as StevensJohnson syndrome and exfoliative dermatitis, have also been reported with sildenafil and tadalafil; pruritus and eyelid swelling - with avanafil [24].

Table 2. The most common adverse effects of PDE-5 inhibitors (\% of incidence) [27,30-35]

\begin{tabular}{|l|c|c|c|c|c|}
\hline $\begin{array}{c}\text { Adverse effect } \\
(\%)\end{array}$ & Sildenafil & Tadalafil & Wardenafil & Avanafil & Udenafil \\
\hline \multicolumn{1}{|c|}{ Headache } & $12.8 \%$ & $14.5 \%$ & $16 \%$ & $9.3 \%$ & $1.7 \%$ \\
\hline Flushing & $10.4 \%$ & $4.1 \%$ & $12 \%$ & $3.7 \%$ & $8.3 \%$ \\
\hline Dyspepsia & $4.6 \%$ & $12.3 \%$ & $4 \%$ & $1.4 \%$ & - \\
\hline $\begin{array}{l}\text { Nasal } \\
\text { congestion }\end{array}$ & $1.1 \%$ & $4.3 \%$ & $10 \%$ & $1.9 \%$ & - \\
\hline Dizziness & $1.2 \%$ & $2.3 \%$ & $2 \%$ & $0.6 \%$ & $1 \%$ \\
\hline $\begin{array}{l}\text { Abnormal } \\
\text { vision }\end{array}$ & $1.9 \%$ & - & - & - & - \\
\hline Backache & - & $6.5 \%$ & - & $1.1 \%$ & - \\
\hline Myalgia & - & $5.7 \%$ & - & - & - \\
\hline
\end{tabular}

\section{INTERACTIONS}

It is crucial to pay attention to appropriate dosing. A consecutive pill may be taken only after 24 hours. Meanwhile, no other ED treating drugs may be used. Furthermore, it is advisable to avoid taking the drug along with fatty food, as it may alleviate its effect. In addition, it is inadvisable to wash the drug down with grapefruit juice (other kinds of fruit juice are not recommended as well), since it blocks the CYP3A4 enzyme responsible for the metabolism of PDE-5 inhibitors, which may intensify their side-effects in the same way as alcohol does [36,37].

The most serious undesirable effects, however, result from drug interactions. In this case, the concomitant use of PDF-5 inhibitors with CYP3A4 inducers and inhibitors is of great importance because of their extensive CYP3A4 metabolism, thus, dosage adjustment should be considered

Table 1. PDE-5 inhibitor comparison [10, 24-29]

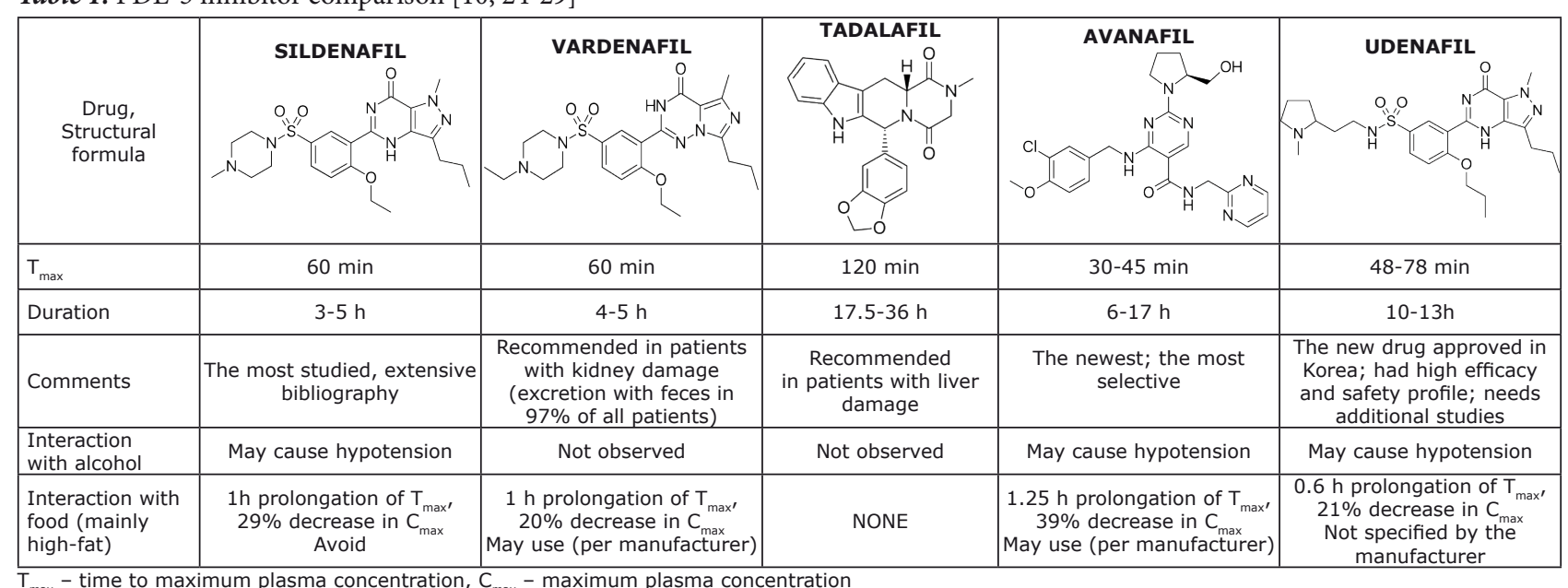


(see Contraindications). What is more, PDF-5 inhibitors are inadvisable in patients who use nitrates (nitroglycerin, pentaerythritol) and other NO donors (e.g. molsidomine). This inadvisability alert results from the accumulation of second messenger cGMP and tendency towards significant vasodilatory (headache, flushing) and hypotensive symptoms: from dizziness, faintness, vertigo, to potentially fatal orthostatic hypotension. Nitrates deliver egzogenic NO, thus producing cGMP and PDE-5 inhibitors, which, according to their mechanism of action, inhibit PDE-5 enzyme activity and also increase the concentration of cGMP. In patients with acute chest pain, nitrate administration must be delayed for at least $24 \mathrm{~h}$ after PDE-5 inhibitor administration. In the case of long acting drugs, the dosage should be delayed for further 24h [38-41]. Patients using alpha-blockers (e.g. doxazosin, terazosin) [42] also ought to use smaller doses of the drug. Finally, it is recommended not to combine sildenafil or tadalafil with other potence-intensifying drugs (Revatio ${ }^{\circledR}$, Adcirca ${ }^{\circledR}$, or the pulmonary arterial hypertension drug, PAH) or to double it [9,24,30-35].

\section{CONTRAINDICATIONS}

Selective PDE-5 inhibitors are contraindicated in patients with a known hypersensitivity to any component of the preparation, in patients treated with nitrates (regularly or intermittently), in those who have suffered from stroke or acute coronary syndrome during the previous 6 months, hypotension $<90 / 50 \mathrm{~mm} \mathrm{Hg}$, as well as uncontrolled arterial hypertension $>170 / 100 \mathrm{~mm} \mathrm{Hg}$. Other contraindications inlude congestive cardiac failure (classes II-IV according to New York Heart Association, NYHA), acute liver failure (class C in Child and Pugh's classification) and kidney failure characterized by GFR $<30 \mathrm{ml} / \mathrm{min}$. Moreover, they should not be mixed with CYP3A4 inhibitory drugs from the group of antifungals (ketoconazole and itraconazole), antiviral agents (ritonavir, atazanavir, indinavir, nelfinavir and saquinavir), antibiotics (erythromycin, clarithromycin and telithromycin), antidepressants (trazodone and nefazodone) due to inhibition of their metabolism, and increased concentration in the blood. The application of PDE5 inhibitors also requires special attention in people with anatomical penile deformities and diseases predisposing to priapism (sickle-cell anemia, multiple myeloma and leukemia) [24,43].

\section{CONCLUSION}

The availability of sildenafil without prescription (over the counter, OTC) enables patients suffering from ED to use an effective drug. Nevertheless, it involves plenty of threats. Delaying a visit to a medical practitioner may delay the diagnosis of associated diseases. What is more, taking medication without the specialist control may lead to uncontrolled increase in dosing: many men on their own may take two, four or even more tablets. Available OTC sildenafil may also be used by adolescents as a method of sexual doping. In addition, patients may not be aware of the threat coming with drug interactions, thus, consultation with a pharmacist is an indispensable element while selling the preparations.

\section{REFERENCES}

1. NIH Consensus Conference. Impotence. NIH Consensus Development Panel on Impotence. JAMA.1993;270(1):83-90.

2. Gong B, Ma M, Xie W, Yang X, Huang Y, Sun T et al. Direct comparison of tadalafil with sildenafil for the treatment of erectile dysfunction: a systematic review and meta-analysis. Int Urol Nephrol. 2017;49(10):1731-40. doi: 10.1007/s11255-017-1644-5.

3. Izdebski Z. Seksualność Polaków na początku XXI wieku. Studium badawcze. Kraków: Wyd. UJ; 2012:287-92.

4. Szurgociński A. Zaburzenia erekcji w Polsce. Grodzisk Mazowiecki: Vedi Clinic;2016.

5. Moreland RB, Hsieh G, Nakane M, Brioni JD. The biochemical and neurologic basis for the treatment of male erectile dysfunction. J Pharmacol Exp Ther. 2001;296(2):225-34.

6. Rabijewski M. Zaburzenia erekcji - etiologia i leczenie. Przegl. Urol. 2006;4(38):46.

7. Izdebski Z. Obawy i trudności w życiu seksualnym. Rocz Lubus. 2006;32(2):13-8.

8. Dęmbe K, Jasik M, Stawicki S, Karnafel W. Patogeneza i częstość zaburzeń erekcji u chorych na cukrzycę. Seksuol Pol. 2004;2 (2):51-54.

9. Hatzimouratidis K, Amar E, Eardley I, Giuliano F, Hatzichristou D, Montorsi F et al. Guidelines on male sexual dysfunction: erectile dysfunction and premature ejaculation. Eur Urol. 2010;57(5):804-14. doi: 10.1016/j.eururo.2010.02.020.

10. Ferguson JE, Carson CC. Phosphodiesterase type 5 inhibitors as a treatment for erectile dysfunction: Current information and new horizons. Arab J Urol. 2013;11(3):222-229. doi: 10.1016/j. aju.2013.07.009.

11. Woroń J, Kostka-Trąbka E. Zaburzenia erekcji jako wynik niepożądanego działania leków. Seksuol Pol. 2005;3:18-22.

12. Rew KT, Heidelbaugh JJ. Erectile dysfunction. Am Fam Physician. 2016;94(10):820-827.

13. Rosen RC. Psychogenic erectile dysfunction. Classification and management. Urol Clin North Am. 2001;28(2):269-78.

14. Reisman Y, Hind A, Varaneckas A, Motil I. Efficacy and Safety of Linear Focused Shockwaves for Erectile Dysfunction (RENOVA)-A Second Generation Technology. Int J Impot Res. 2015;27(3):108-12. doi: 10.1038/ijir.2014.41.

15. Snyder PJ, Ellenberg SS, Farrar JT. Effects of testosterone treatment in older men. N Engl J Med. 2016;374(7):611-24. doi: 10.1056/NEJMc 1603665.

16. Anaissie J, Hellstrom WJ. Clinical use of alprostadil topical cream in patients with erectile dysfunction: a review. Res Rep Urol. 2016;8:123.

17. Altwein JE, Keuler FU. Oral treatment of erectile dysfunction with apomorphine SL. Urol Int. 2001;67(4):257-63.

18. Rabijewski M, Papierska L. Pathogenesis and treatment of erectile dysfunction. Ger Pol. 2007;1:203-8.

19. Goldstein I, Lue TF, Padma-Nathan H, Rosen RC, Steers WD, Wicker PA. Oral sildenafil in the treatment of erectile dysfunction. N Engl J Med. 1998;338(20):1397-1404.

20. McCullough AR. Four-year review of sildenafil citrate. Reviews in Urology. 2002;4,Suppl 3:26.

21. Hackett G, Kell P, Ralph D, Dean J, Price D, Speakman M et al. British society for sexual medicine guidelines on the management of erectile dysfunction. J Sex Med. 2008;5:1841-65.

22. Lew-Starowicz Z. Inhibitory fosfodiesterazy typu 5 - podobieństwa i różnice. Seksuol Pol. 2003;(2):79-82.

23. Liu Y. The tale of Viagra patents: comparative studies of the global challenges in China and other countries. 2013;18:523-33.

24. Huang SA, Lie JD. Phosphodiesterase-5 (PDE5) Inhibitors In the Management of Erectile Dysfunction. P T. 2013;38(7):407-19.

25. Jiann BP. Evolution of phosphodiesterase type 5 inhibitors in treatment of erectile dysfunction in Taiwan. Urol Sci. 2016;27 (2):66-70.

26. Cho MC, Paick JS. Udenafil for the treatment of erectile dysfunction. Ther Clin Risk Manag. 2014;10:341-54. doi: 10.2147/TCRM.S39727. 
27. Zhao C, Kim SW, Yang DJ, Kim JJ, Park NC, Lee SW et al. Efficacy and Safety of Once-Daily Dosing of Udenafil in the Treatment of Erectile Dysfunction: Results of a Multicenter, Randomized, DoubleBlind, Placebo-Controlled Trial. Eur Urol. 2011;60(2):380-7. doi: 10.1016/j.eururo.2011.03.025.

28. Kim TE, Kim BH, Kim JR, Lim KS, Hong JH, Kim KP et al. Effect of food on the pharmacokinetics of the oral phosphodiesterase 5 inhibitor udenafil for the treatment of erectile dysfunction. Br J Clin Pharmacol. 2009;68(1):43-6. doi: 10.1111/j.1365-2125.2009.03404.x.

29. http://www.mims.com/malaysia/drug/info/zydena/

30. Levitra ${ }^{\circ}$ (vardenafil) Scientific Discussion \& Summary of Product Characteristics. European Medicine Agency: London, GB. 2009. Last update: 06/04/2017

31. Cialis ${ }^{\otimes}$ (tadalafil) Scientific Discussion \& Summary of Product Characteristics. European Medicine Agency: London, GB. 2007. Last update: 15/06/2016.

32. Viagra ${ }^{\circ}$ (sildenafil) Scientific Discussion \& Summary of Product Characteristics. European Medicine Agency: London, GB. 2008. Last update: 12/07/2016

33. Spedra ${ }^{\circ}$ (avanafil) Scientific Discussion \& Summary of Product Characteristics. European Medicine Agency: London, GB. 2013. Last update: 10/03/2015

34. Stendra (avanafil), prescribing information. Mountainview, Calif.: Vivus, Inc.; April 2012.

35. Staxyn (vardenafil ODT), prescribing information. Wayne, NJ.; Bayer Healthcare/GlaxoSmithKline; revised April 2011.
36. Warrington JS, Shader RI, von Moltke LL, Greenblatt DJ. In vitro biotransformation of sildenafil (Viagra): identification of human cytochromes and potential drug interactions. Drug Metab Dispos. 2000;28(4):392-7.

37. Jetter A, Kinzig-Schippers M, Walchner-Bonjean M, Hering U, Bulitta J, Schreiner P et al. Effects of grapefruit juice on the pharmacokinetics of sildenafil. Clin Pharmacol Ther 2002;71(1):21-9.

38. Young JM. Vardenafil. Expert. Opin. Investig. Drugs 2002;11:1487-96.

39. Gresser U, Gleiter $\mathrm{CH}$. Erectile dysfunction: comparison of efficacy and side effects of the PDE-5 inhibitors sildenafil, vardenafil and tadalafil - review of the literature. Eur. J. Med. Res. 2002;7:435-46.

40. Kloner RA, Mullin SH, Shook T et al. Erectile dysfunction in the cardiac patient: how common and should we treat? J. Urol. 2003;170 (2):S46-50

41. Swearingen D, Nehra A, Morelos S, Peterson CA. Hemodynamic effect of avanafil and glyceryl trinitrate coadministration. Drugs Context. 2013;26:212248. doi: 10.7573/dic.212248.

42. Giuliano F, Jackson G, Montorsi F, Martin-Morales A, Raillard P et al. Safety of sildenafi 1 citrate: review of 67 double-blind placebocontrolled trials and the postmarketing safety database. Int J Clin Pract. 2010;64(2):240-55.

43. Kuczerowski R. Nowe możliwości leczenia zaburzeń erekcji u mężczyzn z cukrzycą typu 2. Diabetologia Kliniczna 2015;4 (4):15862. doi: 10.5603/DK.2015.0017. 